\title{
An Anti-Unfair Competition Law Without a Core: An Introductory Comparison Between U.S. Antitrust Law and the New Law of the People's Republic of China
}

\section{Tianlong $Y u^{*}$}

\section{INTRODUCTION}

On September 2, 1993, China's legislative body, the National People's Congress, passed the Anti-Unfair Competition Law of the People's Republic of China (hereinafter "the New Law"), which came into effect on December 1, 1993.' This Article provides a thorough introduction to the New Law and makes both structural and conceptual comparisons between the New Law and key United States antitrust laws. This introduction and comparison will not only help American companies doing, or planning to do, business in China understand the New Law and its impact on their business operations in China, but will also help American lawyers understand the New Law for the benefit of their international practice.

The New Law is the first statute China has promulgated in the anti-unfair competition/antitrust law area. In contrast, the United States has enacted a number of key antitrust statutes, including the Sherman Act, the Clayton Act (as amended by Robinson-Patman Act), and the

* Chinese Business and Law Consultant, Ice Miller Donadio \& Ryan, Indianapolis; Acting Dean of Hangzhou University Law Department, Hangzhou, China, 1988-90; Director of Hangzhou University International Commercial Law Research Center, 1988-1990; and Chief Vice Chairman of International Law Research Society of Zhejiang Province, 1988-90.

J.D. Candidate, 1995, Indiana University School of Law-Indianapolis; MCL, 1987, Indiana University School of Law Bloomington; LLB, 1983, East China Institute of Politics and Law, Shanghai, China.

1. The New Law has not been codified. All citations to the New Law in this Article are from the People's Daily (Overseas Edition), September 7, 1993, which published the New Law. No citation will be provided hereinafter except article numbers of the New Law. Also, there will be no official translation in English of the New Law. The English provisions cited in this Article are the Author's translation, and are only excerpts of the New Law. In case that such translation varies in meaning from the official version in Chinese, the latter shall control. 
Federal Trade Commission Act ("FTC Act"). ${ }^{2}$ China has been in the process of economic reform since the late 1970s, converting the old "planned economy" system, copied from the former Soviet Union in the early 1950s, into the so-called "socialist market economy" system. Although no ideal definition has been developed as to what the "socialist market economy" should really look like, it has been widely perceived as an economy in which the market mechanism plays a crucial role. Under the old planned economy system, competition made little sense because everything, theoretically, was to be planned (although "planned" does not necessarily mean "achieved"). However, in the newly introduced market economy system, nothing seems more important than fair competition and its protection. Article 1 of the New Law clearly states: "This law is enacted in order to ensure the healthy development of the socialist market economy, encourage and protect fair competition, crack down on acts of unfair competition, and protect the legal rights and interests of business owners and consumers."

The New Law is significant for many reasons: (1) It is China's first legislation recognizing fair competition; (2) it provides necessary protection for the development of a market mechanism, although such protection under the New Law is very primary and limited; and (3) the New Law also means additional legal protection for the interests of foreign investors in China, especially those with investments related to trademarks and trade secrets. It is expected that the enactment of the New Law will improve China's overall environment for foreign investment. .

The United States is the third largest investor in China, with total direct investment of nearly 7 billion U.S. dollars as of the end of 1993 . Therefore, it is important for American companies which are doing or intend to do business in China to know both the similarities and the differences between the New Law and U.S. antitrust laws. With the promulgation of the New Law, questions which may arise among such American companies include: (1) Does the New Law prohibit unfair practices similar to United States antitrust laws? (2) Does the New Law provide similar remedies or penalties for violations? (3) Who will be the enforcing agency? (4) How is the New Law enforced?

This Article answers these questions through an introduction to the New Law and a comparison with U.S. antitrust laws. This Article primarily focuses on examining the meaning of unfair acts and the

2. The Sherman Act, 15 U.S.C. 1-7; The Clayton Act, 15 U.S.C. $\$ 12-$ 27; F.T.C. Act, 15 U.S.C. 41-58. 
respective categories listed under the New Law. In addition, this Article also examines the primary legal remedies and penalties imposed under the New Law, the power of the government agencies which enforce the New Law (hereinafter the "enforcing agencies"), and the procedures used by the enforcing agencies. At each stage, comparisons will be made to relevant parts of the U.S. antitrust laws.

\section{Unfair Competitive Acts Defined and Enumerated}

The New Law defines acts of unfair competition as "those which are in violation of the provisions of the New Law, cause damage to the legal rights and interests of other business operators, and disrupt the socio-economic order."'3 This definition contains three elements: violation of the New Law, damage to other parties, and disruption to the socio-economic order.

The first element is most important because it defines the precise scope of application of the law. In other words, only those acts which are listed in, and clearly declared unlawful by, the New Law will be treated as unfair acts. The New Law does not apply to acts not enumerated in, and therefore not prohibited by, the New Law, no matter how unfair the act might seem.

The second element provides a ground for civil damage recovery for business operators whose legal rights and interests are invaded by the unfair acts. However, this element is not a prerequisite for holding some acts to be unfair. As will be discussed below, ${ }^{4}$ the enforcing agencies may declare that certain actions constitute unfair practices and may impose sanctions without any proof of damages to other parties.

The third element, disruption to the socio-economic order, does not provide any practical guidance in determining whether certain conduct constitutes unfair competition. Virtually any conduct which is in violation of the provisions of the New Law and/or causes damage to other business operators' legal rights and interests can readily be labeled as conduct which disrupts the socio-economic order.

Under U.S. antitrust laws, there seems to exist no comprehensive definition as to what constitutes an unfair act. Rather, specific types of unfair practices are defined in statutes such as the Sherman Act, the Clayton Act, the Robinson-Patman Act, and the FTC Act. Nevertheless, the following language of Section 5 of the FTC Act appears to serve as a general definition for anti-competitive behavior: "Unfair

3. New Law, art. 2, para. 2.

4. See infra Part IV. 
methods of competition in or affecting commerce, and unfair or deceptive acts or practices in or affecting commerce ...."s

Unlike the definition in the New Law, Section 5 of the FTC Act distinguishes "unfair methods of competition" from "unfair (or deceptive) acts or practices." The former refers to those practices which are specifically prohibited by the Sherman, Clayton and RobinsonPatman Acts, including horizontal and vertical price fixing, horizontal market allocations, anti-competitive group boycotts, competitively unreasonable exclusive dealing, monopolization, attempted monopolization, and conspiracies to monopolize. The latter refers primarily to unfair or deceptive marketing techniques, including fraudulent advertising and misleading product promotions.

The New Law specifically prohibits several unfair practices. The following provides a sketch of those prohibitions.

\section{A. Acts Relating to Trademark Infringement}

Article 5 of the New Law reads:

Business operators may not cause damages to its competitors by utilizing the following unfair methods to conduct business transactions:

A. counterfeiting others' registered trademarks;

B. causing confusion between their products with well-known products and making a buyer mistake one commodity for said well-known products by using the names, packaging or decoration of well-known products without authorization, or by using names, packaging or decoration closely similar to the wellknown products;

C. causing consumers to mistake one's commodity for another's by using the names of other enterprises or individuals;

D. making misleading or fraudulent representations on a commodity's quality by forging or counterfeiting quality marks including certified quality marks and famous/excellent quality marks, by fabricating the origin of production, or by making fraudulent and/ or misleading representation about the quality of the commodities. 
Trademark infringements and other related conduct are prohibited primarily under China's Trademark Law. ${ }^{6}$ Article 5 of the New Law repeats this prohibition. By listing trademark infringement and other related acts as unfair conduct, the New Law provides additional protection to the party whose trademark is infringed.

\section{B. Certain Acts by Public Utilities Enterprises and Exclusive Dealers}

Article 6 of the New Law provides in pertinent part:

Public utilities enterprises and other business operators which enjoy the status of exclusive dealing privileges under the laws shall not force others to purchase goods/services from the business operators designated by them in order to push out other business operators' fair competition.

The enterprises referred to in this Article of the New Law include those in the industries of energy, transportation, telecommunications, water supply, and others which are critical to the national economy and people's daily life. In the past, these industries were substantially monopolized by the government or by agencies directly authorized by the government. However, since the late 1980 s, the Chinese government has gradually opened some of these industries to the private sector and to foreign investment as part of its foreign investment inducement policy. As a result, there have emerged some "competitors" in some of these areas, including joint venture railroad ownership, joint venture power stations, joint venture highways, and joint venture wharfs. Article 6 of the New Law reflects such transitional changes, and intends to protect the interests of the new competitors, including American investors, in these areas. However, good intentions do not always square with reality.

Article 6, with its ambiguous wording, will become one of the most difficult articles in the New Law to be enforced. The reality in China seems to be that substantial parts of the public utilities industries are still under the control of either the central or local government, that free market mechanisms, especially with respect to the prices of the products or services in those industries, have not yet been playing the dominant role, and that most of the Chinese entities in utilities industries are merely government agencies with a business or corporate outfit. In such circumstances, fair competition for the new competitors is merely a hope rather than a reality. In the United States, since

6. People's Republic of China Trademark Law, art. 38. 
utilities industries have never been in the same position as the Chinese utilities industries have, there are no legislative provisions in U.S. antitrust laws comparable to Article 6 of the New Law.

\section{Acts Related to Administrative Functions}

Article 7 of the New Law states:

The government and its subordinated offices shall not abuse their administrative power to force others to purchase goods or services of the business operators designated by the government, or to impose limits upon the business activities of other business operators.

Government and its subordinated offices shall not abuse its administrative power to limit the entry of goods or services from outside regions into local markets, or vice versa.

This is another Article which is unique in the Chinese anti-unfair competition law system. Like Article 6, Article 7 reflects certain transitional changes. On one hand, Article 7 demands the free flow of goods or services and limits administrative interference with free competition. On the other hand, the word "abuse" sets the tone, implying that as long as government and its subordinated offices do not abuse their administrative power, they may still, to a certain extent, force others to purchase goods or services of business operators designated by the government, impose limits upon the business activities of other business operators, and/or limit the free flow of goods or services.

While any provision like Article 7 in U.S. antitrust laws would be unthinkable, the restriction under Article 7 may still seem to be a reasonable step in the transition from a fully-planned economy toward a market economy. Free competition and the market mechanism cannot be established overnight simply by abandoning the old economic system, regardless of how unreasonable it may have been.

\section{Acts Related to Commercial Bribery, Kickbacks, and Discounts}

Article 8 of the New Law declares:

Business operations shall not promote the sale or purchase of goods or services by using bribery in the form of property or otherwise. It should be treated as bribery when one business operator pays secret kick-backs outside the accounting records; it should be treated as acceptance of bribery if the entity or individual of the other side receives the secret kick-backs outside the accounting records. 
During the sale or purchase of goods or services, a business operator may expressly give the other party a discount, or pay a commission to broker, to the extent that such discount and commission must be recorded for accounting purposes. The business operator who accepts such discount or commission must also record it for accounting purposes.

Article 8 clearly prohibits commercial bribery, including secret kick-backs. However, this Article does not prohibit discounts and commissions if the discount or commission is recorded for accounting purposes. Commercial bribery and secret discounts or commissions are common practice in China, especially among entities in the private sector, which often use them as efficient techniques to compete with state-owned enterprises. Therefore, Article 8 of the New Law will have much more impact upon the business entities in the private sector.

\section{E. Acts Related to Advertisements}

Article 9 of the New Law provides:

Business operators shall not, by advertisement or other means, make fraudulent or misleading descriptions of a commodities' quality, ingredients, function, use, manufacturer, expiration limit or production place.

Advertisers, having knowledge or having reason to know, shall not represent such business operators in designing, producing. and releasing to the public such fraudulent or misleading advertisements.

Article 9 aims to crack down on unfair product promotion techniques, which are also common practices in China. It is important to note that Article 9 not only prohibits business operators from making fraudulent or misleading advertisements, but also prohibits advertisers from knowingly making such fraudulent or misleading advertisements.

\section{F. Acts Infringing Trade Secrets}

Article 10 of the New Law provides:

Business operators shall not infringe trade secrets in the following means:

A. obtaining trade secrets of others through theft, inducement, duress, or other unfair means;

B. disclosing, utilizing or franchising trade secrets of others which are obtained in the manner described in the preceding paragraph; 
C. disclosing, utilizing or franchising the trade secrets under its control, in breach of an agreement or a confidentiality demand by the trade secret owner.

Acts of a third party who obtains, utilizes, or discloses others' trade secrets with the knowledge that such acts as listed above are unlawful should be treated as infringing those trade secrets.

Article 10 further defines trade secrets as "technological information or business information which is unknown to the public, may generate economic benefit to the owner, is practical, and is protected by the owner with certain measures."

\section{G. Acts Related to Commodity Distribution}

The New Law prohibits three types of acts which are related to commodity distribution. Article 11 of the New Law provides: "Business operators shall not, for the purpose of pushing out competition, sell goods or services at a price which is lower than cost." However, Article 11 lists the following as exceptions; selling fresh and live goods, disposing of goods whose time limit is to expire or which has been in inventory for a long time, seasonal discounts, or selling goods for the reasons of paying debt, changing the line of production, or winding up.

Article 12 of the New Law provides: "In selling commodities, a business operator shall not, against the buyer's will, tie one commodity's availability to the purchase of another, or put unreasonable conditions upon purchasing."

Article 13 of the New Law provides:

Business operators shall not sell commodities in the following forms of sweepstake:

A. deceptive sweepstake sale in which there virtually exists no sweepstake awards, or in which the winners of the awards are predecided;

B. using sweepstake sale to sell low quality commodities at high prices;

C. sweepstake sale in which the highest prize exceeds 5,000 Yuan.?

7. The current exchange rate between the U.S. dollar and the Chinese Yuan is 8.699 yuan per U.S. dollar. Wall St. J., April 18, 1994, at C6. 


\section{H. Acts Detrimental to Competitors' Business Reputation}

Article 14 of the New Law provides: "Business operators shall not fabricate or spread false rumors to damage the business trustworthiness and reputation of its business competitors."

\section{Concerted Acts in Bidding}

Article 15 of the New Law provides:

Bidders shall not make tenders in conspiracy for the purpose of increasing or decreasing the bidding price.

Bidder and bid inviter shall not conspire with each other to push out other parties' fair competition.

\section{Comparison of Violations Under the New Law and U.S. ANTITRUST LAws}

Reviewing the above anti-competitive acts established by the New Law, and comparing what exists under the U.S. antitrust laws, several significant differences should be noted.

\section{A. The Core Part of Antitrust Law Violations Is Missing in the New Law}

The traditional violations under U.S. antitrust laws include (1) horizontal and vertical price fixing, as prohibited under Section 1 of the Sherman Act; ${ }^{8}$ (2) tying arrangements and exclusive dealing as prohibited under Section 1 of the Sherman Act and Section 3 of the Clayton Act; ${ }^{9}(3)$ anti-competitive group boycotts as prohibited under Section 1 of the Sherman Act; ${ }^{10}$ (4) anti-competitive monopolization, attempted monopolization and conspiracies to monopolize as prohibited under Section 2 of the Sherman Act; ${ }^{11}$ (5) discriminatory pricing and illegal brokerage payments as prohibited under the Robinson-Patman Act, as amended to Section 2 of the Clayton Act; ${ }^{12}$ and (6) anticompetitive mergers and acquisitions as prohibited under Section 7 of the Clayton Act. ${ }^{13}$ Compared with these traditional antitrust law viol-

\footnotetext{
8. 15 U.S.C. $\$ 1$.

9. Id. 1,14 .

10. Id. $\$ 1$.

11. Id. 2 .

12. Id. $\$ 13(\mathrm{a}),(\mathrm{c})$.

13. Id. 18 .
} 
ations existing in U.S. antitrust laws, the New Law lists only a few such traditional antitrust violations with significant conceptual variations.

\section{Tying and Conditioned Dealing}

Tying arrangements and certain conditioned sales/purchases are prohibited by the New Law under Article 12. However, the language of Article 12 seems to imply that this violation is a unilateral offense on the seller's or service provider's part, rather than a bilateral violation as defined under both Section 1 of the Sherman Act and Section 3 of the Clayton Act. ${ }^{14}$ Also, Article 12 of the New Law does not distinguish concepts such as goods, services, and commodities, and generally prohibits any tying or conditioned purchases or sales. Unlike Article 12 of the New Law, U.S. antitrust laws treat goods, services, and commodities tying arrangements differently under Section 1 of the Sherman Act and Section 3 of the Clayton Act. Finally, as will be discussed in more detail below, the New Law does not provide any specific remedy or penalty for acts in violation of Article 12 .

\section{Commercial Bribery}

Paragraph 1 of Article 8 of the New Law clearly prohibits bribery in commercial transactions. In addition, secret kick-backs outside the accounting records are treated as bribery. Under China's Criminal Law, both giving and accepting a bribe is a crime. ${ }^{15}$

Paragraph 2 of Article 8 deals with secret discounts and commissions in commercial transactions. The New Law does not generally prohibit discounts and commissions, as long as they are reflected in both the payor's and the payee's accounting records.

U.S. antitrust laws treat commercial bribery, illegal brokerage, and discount payments as price discrimination. Section 2(c) of the Clayton Act, which was amended by the Robinson-Patman Act, provides:

It shall be unlawful for any person engaged in commerce, in the course of such commerce, to pay or grant as to receive or accept, anything of value as a commission, brokerage, or other compensation, or any allowance of discount in lieu thereof, except for services rendered in connection with the sale or purchase of goods, wares or merchandise, either to

14. Id. $\$ 1,14$.

15. People's Republic of China Criminal Law, art. 185. 
the other party to such transaction or to an agent, representative, or other intermediary therein. ${ }^{16}$

Comparing Article 8 of the New Law with Section 2(c) of the Clayton Act, as amended by the Robinson-Patman Act, one will find that under Article 8 of the New Law, price discrimination will occur when a seller gives a discount or pays a commission or brokerage only to certain buyers. However, since Section 2(c) of the Clayton Act prohibits any kind of commission, brokerage, discount or other compensation between the buyer and seller, except when services are involved with the sale or purchase of goods or exchanged for other services, it is much less likely that price discrimination will occur.

\section{Conspiracy Violations}

Article 15 of the New Law provides only two types of violations; those which relate to concerted price fixing among bidders, and bilateral conspiracy between bidder and bid invitor against fair competition. Unlike such prohibitions in the narrow scope, U.S. antitrust laws forbid conspired or concerted acts in much broader scope, including price fixing, market allocation, and conspired monopolization. ${ }^{17}$ In fact, most violations occurring under U.S. antitrust laws are bilateral or concerted acts among two or more parties.

\section{Exclusive Dealing}

As indicated above, exclusive dealing is not absolutely prohibited by the New Law. Instead, the New Law only tries to restrict government agencies, public utilities enterprises, and other entities which enjoy the status of exclusive dealing privileges, from abusing their economic power to impair the competition mechanism which is at the beginning stage of its development in China. Unlike the exclusive dealing provisions in the New Law, exclusive dealing in any form is clearly prohibited under Section 3 of the Clayton Act. ${ }^{18}$

16. 15 U.S.C. $\$ 13(\mathrm{c})$.

17. Id. IS $1-3$.

18. Id. $\$ 14$. "It shall be unlawful ... to lease or make a sale or contract for the sale of goods, wares, merchandise, machinery, supplies or other commodities, whether patented or unpatented, for use, consumption or resale, . . . or fix a price charged thereof or discount from, or rebate upon, such price, on the condition, agreement or understanding that the lessee or purchaser thereof shall not use or deal in the goods, ... . where the effect of such lease, sale, or contract for sale or such condition, agreement or understanding may be to substantially lessen competition or tend to create a monopoly in any line of commerce." 


\section{Summary}

The New Law does not contain most of the offenses or violations which are prohibited under U.S. antitrust laws and which are regarded as the principal parts of traditional U.S. antitrust laws. Therefore, it seems fair to conclude that the New Law is an anti-unfair competition law without a core.

The logical explanation seems to be that it is premature or unrealistic to have a truly effective antitrust law in China when the pricing system is still substantially regulated by the government and the economy is still substantially monopolized by the government. Traditional antitrust laws, like those which exist in the United States, prohibit any form of price fixing. Under the basic theory of the free market system, the prices of goods or services shall be the result of fair competition. However, under China's current economic system, despite the price system reform taking place, the prices for substantial numbers of commodities are still subject to government regulations. In other words, it is the government which continues "fixing" these prices. Therefore, it is unthinkable to have anti-price fixing laws on one hand and to let the government "lawfully" fix the prices on the other.

Similarly, with respect to monopolization, while a decentralization process has been underway in China, it is still the government which controls most of the major industries and industrial enterprises. In such circumstances, it is impossible to have a meaningful anti-monopolization law. Although it is said that anti-monopolization laws and other related legislation have been under consideration, it is almost certain that such legislation will not be in force in the near future.

\section{B. Violations Unique Under the New Law}

While the New Law does not contain most of the traditional violations found in U.S. antitrust laws, it does prohibit certain acts which are not found in U.S. antitrust laws. For example, some violations by public utilities enterprises and entities which enjoy exclusive dealing privileges, and acts by certain government agencies abusing administrative power are prohibited. Also, the New Law applies to other acts which are normally not regarded as the subject of U.S. antitrust laws. These violations include infringement of trademarks and trade secrets, acts causing damage to a competitor's business reputation, and illegal sweepstake sales. In the United States, such activities are normally governed by other laws, although it is quite likely that the Federal Trade Commission may still have jurisdiction under the authority vested by Section 5 of the FTC Act against such acts on the broad ground of "unfairness." 


\section{Exhaustive List of Anti-Competitive Acts}

As mentioned at the beginning of this Article, the New Law applies only to specific anti-competitive acts, and does not reach other acts, no matter how unfair they may seem. Although U.S. antitrust legislation also targets specific acts as provided under the Sherman, Clayton, and other key U.S. antitrust laws, ${ }^{19}$ the legislative mechanism adopted in the New Law is totally different from that of Section 5 of the FTC Act. Section 5 of the FTC Act not only empowers the Federal Trade Commission to crack down on violations prohibited under other antitrust laws on the ground that they are "unfair" and "affect interstate commerce," but also empowers the Commission to reach far beyond what the antitrust laws prohibit. There is no exhaustive list in U.S. antitrust law of acts or practices which are expressly prohibited or declared unlawful.

The advantage of having an exhaustive scope, as in the New Law, is that it seemingly makes the enforcing agencies' job much easier when determining what constitutes "unfair" conduct in a given situation. The risk, however, is that some unfair acts could be outside the scope of the law. It is widely recognized that Section 5 of the FTC Act functions partially to fill legislative gaps because it does not have an exhaustive scope with respect to "unfairness." Section 5 gives the Federal Trade Commission the power to reach conduct which is not a clear violation under other antitrust laws. On the other hand, the limit of the FTC's power under Section 5 of the FTC Act has been a controversial issue.

\section{Common Law Influence}

China is a civil law country in which legislation and regulations are the primary sources of law, and the decisions or rulings by courts at any level are not normally regarded as a source of binding law as they are in the United States. Therefore, it is foreseeable that further development in the area of anti-unfair competition/antitrust law can be accomplished only by revising the New Law or enacting other new legislation or regulations. By contrast, although enacted statutes play dominant roles in the American antitrust law area, court decisions have contributed tremendously in its development. In some instances, American courts directly create new legal concepts which are unseen in the antitrust statutes, but are essential to the enforcement and development

19. Supra note 2. 
of American antitrust law. One good example is the invention by courts of the concepts of the "rule of reason" and the "per se" rule. The language of Section 1 of the Sherman Act, which seems to prohibit all concerted activities in restraint of trade, does not even imply such a distinction. However, in an early case, the U.S. Supreme Court held that the Sherman Act only prohibits unreasonable restraints of trade. ${ }^{20}$ In another case decided in 1918, the Court first used the term "rule of reason" as opposed to the "per se" rule. ${ }^{21}$

\section{The Remedies and Penaltites for Violations}

The New Law provides different remedies and penalties for different types of unfair competitive acts as discussed in Part I. The New Law provides only one type of remedy which is available to a private party. Article 20 of the New Law provides that any "[b]usiness operator, whose legal rights and interests are injured by unfair acts, may sue for damages in the people's courts." The same Article also provides the manner by which damages are calculated. Under Article 20, damages should normally be the actual loss incurred by the injured party. However, where it is impossible to calculate the actual loss, the recovery amount should be equal to the actual profit gained by the violator from the illegal conduct. In addition, the injured party may also be entitled to recover reasonable expenses incurred during its investigation of the unfair acts.

The following sections illustrate the penalties which the New Law sets forth for each unfair act.

\section{A. Penalties for Trademark Infringement Related Acts}

Article 21 of the New Law provides different penalties for trademark infringements as defined under Article 5.

\section{Violations of Article 5, Paragraph A}

For violations of Article 5, Paragraph A, the penalties include injunctive orders, civil fines, and/or criminal punishment of persons directly responsible. ${ }^{22}$ Under China's law, such criminal punishment includes up to three years of imprisonment and/or criminal fines. ${ }^{23}$ added).

20. Standard Oil Co. of New Jersey v. U.S., 221 U.S. 1 (1911) (emphasis

21. Chicago Board of Trade v. U.S., 246 U.S. 231 (1918).

22. People's Republic of China Trademark Law, art. 40.

23. People's Republic of China Criminal Law, art. 127. 


\section{Violations of Article 5, Paragraph $B$}

For violations of Article 5, Paragraph B, the penalties set forth under Article 21, Paragraph 2 include one or more of the following: injunctive orders from the enforcing agencies, confiscation of all property and proceeds generated by the violation, fines ranging from one to three times the property value generated by the violation, cancellation of business licenses in case of severe violation, and/or criminal punishment if the violations involve selling commodities with false names and low quality.

\section{Violations of Article 5, Paragraphs $C$ and D}

For violations of Article 5, Paragraphs C and D, Article 21 states that penalties shall be imposed according to the Trademark Law of PRC. Under the PRC Trademark Law, the penalties for acts in violation of the above paragraphs include injunctive orders from the enforcing agencies and/or fines. ${ }^{24}$ Under Section 43 of the Implementing Rules of the PRC Trademark Law, the amount of the fines may be up to 20 percent of the gross gain from the violator's operations, or up to two times the profit generated from the violations.

\section{B. Penalties for Commercial Bribery}

Bribery is criminal conduct under Chinese law, both for the briber and the person accepting the bribe. Article 22 of the New Law provides penalties for acts of commercial bribery. The punishments range from criminal punishment if the violation constitutes a crime, to fines ranging from 10,000 to 200,000 yuan if the violation does not constitute a crime. Confiscation of all the property and proceeds generated from the violations is also possible.

\section{Penalties for Violations by Public Utilities Enterprises and Exclusive Dealers}

Article 23 of the New Law provides the following penalties for violations of Article 6 as discussed in Part II: Injunctive order from the enforcing agencies at a provincial level, or municipal level if such municipality consists of districts; and/or fines ranging from 50,000 to 200,000 yuan.

As Article 6 of the New Law indicates, a third party will be involved in an Article 6 violation, i.e., the party which is designated

24. People's Republic of China Trademark Law, art. 39. 
by the utilities company or an exclusive dealer. Normally, the designated third party is not in the position of violating the New Law. However, if the third party takes advantage of such designation by selling low quality commodities at high prices or charging customers unreasonable fees, it will be subject to similar penalties. Under Article 23 of the New Law, such penalties include confiscation of illegal profits attributable to the violations, and/or fines ranging from one to three times the profit value generated from the violations.

\section{Penalties for Fraudulent Advertisement}

Article 24 of the New Law provides different measures that impose penalties upon business operators and advertisers who violate Article 9 of the New Law. For business operators who violate Article 9, Paragraph 1, the penalties include: Injunctive orders from the enforcing agencies; an order to reduce the impact caused by the fraudulent and misleading advertisements; and/or fines ranging from 10,000 to 200,000 yuan. For advertisers violating Article 9, paragraph 2 of the New Law, the penalties include injunctive orders; confiscation of illegal profits from the violations; and/or fines, for which Article 24 does not specify the amount.

\section{E. Penalties for Trade Secret Infringement}

The penalties for trade secret infringement as defined in Article 10 of the New Law include injunctive orders by the enforcing agencies and/or fines ranging from 10,000 to 200,000 yuan. ${ }^{25}$

\section{F. Penalties for Illegal Sweepstake Sale}

The penalties for commodities sales in the form of sweepstakes as defined in Article 13 of the New Law include injunctive orders by the enforcing agencies and/or fines ranging from 10,000 to 100,000 yuan. ${ }^{26}$

\section{G. Penalties for Conspired Acts in Bidding}

Under Article 27 of the New Law, conspiracies in bidding as defined in Article 15 will render the contract between the parties voịd. In addition, the parties may also be fined an amount ranging from 10,000 to 200,000 yuan.

25. New Law, art. 25.

26. New Law, art. 26. 


\section{H. Penalties for Government Agencies' Violation}

Under Article 30 of the New Law, the immediate superior office shall order its subordinate office to correct any violations of Article 7 of the New Law. If the violation is severe, the individuals who are directly responsible for the violation should receive administrative disciplinary penalties.

\section{Summary}

In summarizing the above eight categories, the penalties provided under the New Law against specific unfair acts include injunctive orders, fines, property confiscation, business license cancellation, and/or criminal punishment. With the exception of criminal punishment, all of the penalties are administrative in nature and are under, the discretion of the enforcing agencies. The enforcing agencies have tremendous discretion in considering whether, and to what extent, certain types of penalties are to be imposed.

Although the New Law provides specific punitive measures for most of the acts of unfair competition enumerated under the New Law, it leaves out two categories without explanation. Specifically, no punishments are listed for selling commodities at prices lower than cost, as defined in Article 11, and the tying arrangements and conditioned sale of commodities as defined in Article 12. Coincidentally, these two types of violations are among those for which it is unlikely that an injured party may successfully invoke Article 20 of the New Law to sue for damages, because both situations make it extremely difficult or even impossible for the injured party's actual losses or the profit gain generated from such violations to be calculated. It appears that the mere prohibition of certain unfair practices without providing any remedies or penalties for the violation will make such prohibition practically unenforceable.

\section{Comparison of Remedies and Penalties Under U.S. Antitrust Laws and The New Law}

We now turn to review the remedies and penalties provided under U. S. antitrust law and compare them with those provided under the New Law.

\section{A. Remedies Under U.S. Antitrust Laws}

The remedies provided under U. S. antitrust laws take mainly two forms: injunctive relief and damages. 


\section{Injunctive relief}

Section 16 of the Clayton Act, which is the primary statutory source for private injunctive relief, provides in relevant part that "[a]ny person, firm, corporation, or association shall be entitled to sue for and have injunctive relief, in any court of the United States having jurisdiction over parties, against threatened loss or damage by a violation of the antitrust laws." 27

In addition to the injunctive relief initiated by a private party, the Clayton Act also provides two additional injunctive proceedings. First, Section 15 of the Clayton Act empowers the Justice Department to institute proceedings in equity to prevent and restrain violations of antitrust laws by way of petitioning the district court. ${ }^{28}$ Second, Section 11 of the Clayton Act empowers the Federal Trade Commission to issue cease and desist orders against an entity or an individual whom the Commission has found in violation of antitrust laws. ${ }^{29}$ The Federal Trade Commission may also bring court action to enforce injunctive orders. ${ }^{30}$

In comparison to the injunctive relief available under U.S. antitrust laws, the injunctive relief provided under the New Law is different in two respects. First, there is no private injunctive relief available under the New Law. According to the relevant provisions of the New Law, it seems to be the enforcing agencies' discretion to issue injunctive orders. This is the main reason injunctive orders by the enforcing agencies are treated as punitive measures, rather than a remedy available to private parties. However, under U.S. antitrust laws, as mentioned above, injunctive relief can be sought either by an individual party or by the Justice Department.

Secondly, the New Law vests the power to issue injunctive orders solely in the enforcing agencies, although subject to judicial review. Under the U. S. antitrust laws, however, such power is within the federal courts' jurisdiction, with the exception that the Federal Trade Commission may issue its own injunctive orders according to Section 11 of the Clayton Act. ${ }^{31}$ Such injunctive orders by the Federal Trade Commission are similar to those of the enforcing agencies under the New Law to the extent that both of them are administrative in nature, and both are subject to judicial review.

27. 15 U.S.C. 26.

28. Id. \25.

29. Id. $\int 21$.

30. Id.

31. Id. $\ 21(\mathrm{~b})$. 


\section{Damages}

Section 4 of the Clayton Act, which is the primary statutory source for damage relief for violation of $U$. S. antitrust laws, provides in relevant part that:

Any person who shall be injured in his business or property by reason of anything forbidden in the antitrust laws may sue therefore in any district court of the United States ... and shall recover threefold the damages by him sustained, and the cost of suit, including a reasonable attorneys' fee. ${ }^{32}$

In comparing this statutory language with that of Article 20 of the New Law, there are two main differences between the New Law and U.S. antitrust laws regarding damages. First, U.S. antitrust laws provide treble damages, while the New Law only permits recovery of actual losses, or the amount of the profit generated from the violations in case the actual loss cannot be calculated. While the "actual loss" standard is consistent with the fundamental Chinese civil law principle that an aggrieved party shall not be enriched from other people's wrongdoing, it seems that this measure will not be as efficient in deterring violations as the treble damage measure in the U.S. antitrust laws. Second, U.S. antitrust laws also allow recovery of the costs of suit, including reasonable attorney's fees, while Article 20 of the New Law allows only reasonable expenses incurred by the injured party during its investigation of the violation.

\section{B. Penalties Under the U.S. Antitrust Laws}

U.S. antitrust laws provide two main types of criminal penalties for violations: fines and imprisonment. Sections 1 and 2 of the Sherman Act respectively provide fines for violations up to ten million dollars by corporations, and up to $\$ 350,000$ for other entities or individuals. ${ }^{33}$ The same sections also provide up to three years of imprisonment with or without fines. In addition to the criminal fines provided in the Sherman Act, civil fines may be levied under the Clayton Act, as well. For example, the Clayton Act imposes fines of up to $\$ 10,000$ per day on individual officers and directors who fail to comply with Section $7 \mathrm{~A} .{ }^{34}$

32. Id. $\$ 15$.

33. Id. IS 1-2.

34. Id. $18 \mathrm{a}$. 
As discussed above, the New Law also provides both fines and criminal penalties for violations of certain provisions of the New Law. However, differences exist between the fines and criminal penalties provided under the New Law and U.S. antitrust laws. First, all of the fines provided directly under the New Law are civil in nature, and are imposed under the full discretion of the enforcing agencies, which are administrative agencies. Under U.S. antitrust laws, the court is ultimately empowered to determine and impose fines for violations. Moreover, unlike the U.S. antitrust laws, the New Law does not provide separate fines for corporate and individual violations. Any business operator violating the relevant provisions of the New Law is subject to the same fines, regardless if it is a corporation, a non-corporate business entity, or an individual. Finally, unlike the U.S. antitrust laws, the New Law provides different fines for different violations, ostensibly according to their detrimental impact. Such fines include up to 20 percent, or two times, the profit from the violation; ${ }^{35} 10,000$ to 100,000 yuan; ${ }^{36} 10,000$ to 200,000 yuan; $;^{37} 50,000$ to 200,000 yuan; ${ }^{38}$ or from one to three times the profit from the violation. ${ }^{39}$

Second, the New Law does not directly provide any criminal punishment for any of the unfair acts listed thereunder. Rather, criminal penalties (including imprisonment and/or criminal fines) are to be imposed under the New Law only when such violations have constituted violations of China's criminal law or other laws which specifically impose criminal penalties. ${ }^{40}$

In addition to the foregoing remedies and penalties, the U.S. antitrust laws also empower the Justice Department and the Federal Trade Commission to take other remedial measures. Such potential measures include forced divestiture of acquired stock or assets, corporate spinoffs, compulsory purchase or sale of needed materials, compulsory sharing of technology, and temporary restrictions upon the defendant's output. ${ }^{41}$ In addition to injunctive relief, damage recovery, fines, and criminal penalties, the New Law provides for other penalties, including confiscation of gain from violations, compulsory elimination of the

35. New Law, art. 21; People's Republic of China, Implementing Rules of the Trademark Law, art. 43.

36. New Law, art. 26.

37. Id. art. $22,24,25$ and 27.

38. Id. art. 23.

39. Id. art. $21,23,28$ and 30 .

40. Id. art. $21,22,31$ and 32 .

41. See William C. Holmes, Antitrust law Handbook 453 (1993). 
detrimental impact from the violations, and cancellation of business licenses.

These comparisons regarding the legal remedies and penalties under the New Law and U.S. antitrust laws are intended only to be general and introductory, since some of the remedies and penalties provided in the law of one country (especially those under the U.S. antitrust laws) are applicable to certain specific violations which may not exist in the other country.

\section{The Enforcing Agencies and Procedures}

Article 3 of the New Law designates the Industry and Commerce Administration offices at county or higher levels as the enforcing agencies. However, Article 3 also provides that if other laws or administrative regulations specifically designate other law enforcing agencies, such agencies shall function as required. One example of such an agency is the prosecutor's offices, which have the power to initiate criminal investigations or file suits if a violation of the New Law constitutes a crime.

In addition to designating specific agencies to enforce the New Law, the New Law also operates to "encourage, support and protect any organization or individual to provide social superintendence against unfair competitive acts." 42 This language seems to imply that any organization or individual may file a violation complaint or report to the enforcing agencies, regardless of whether the organization or individual is a victim of the violation or not.

In addition to the power to impose penalties as discussed in Part II, the New Law also vests investigative power in the enforcing agencies. Under the law, the enforcing agencies may specifically use the following investigative powers in handling cases of unfair competition:

1. In accordance with certain procedures, questioning business operators whose conduct is under investigation, other interested parties and witnesses, and requesting to provide evident material, or other materials which are related to the unfair conduct.

2. Inspecting and copying agreements, accounting books, invoices, documents, records, business communication notes and/or other materials which are related to the unfair conduct.

42. New Law, art. 4 . 
3. Inspecting property or other items which are related to the unfair acts as defined in Article 5 of the Law. When necessary, the agencies may order the business operators under investigation to explain the source and amount of the goods in question, to suspend selling, to be prepared for inspection and to stop transferring, hiding or destroying the property or item under investigation. ${ }^{43}$

Although the New Law gives the enforcing agencies tremendous power to crack down on unfair competition, the decisions made by such agencies are subject to both administrative and judicial review. Under the New Law, a party who declines to accept the agency's decision may petition its immediate competent superior authorities for review of the decision within 15 days of receiving the decision from the agency. If the party further declines to accept the review decision by its superior authorities, it may bring an action in court for judicial review. ${ }^{44}$ However, the superior level administration review is not a necessary step for judicial review. The party who declines to accept the initial decision by the enforcing agency may bring an action directly in court. $^{45}$

Article 29 of the New Law may cause administrative problems due to its confusing wording. According to the language of Article 29, the administration review agency seems to be the immediate competent superior authority of the petitioner, instead of that of the enforcing agency which makes the initial decision. If this reading is correct, the reviewing authorities may not be in a position to alter or overrule the initial decision made by the enforcing agencies at certain levels, because they are parallel government agencies.

Both similarities and differences exist between the New Law and U.S. antitrust laws with respect to law enforcement initiatives and procedures. Under the Sherman Act, the Justice Department has exclusive jurisdiction to seek injunctive relief or criminal penalties against conduct in violation of the Act. Unlike the enforcing agencies, the Justice Department may not issue an injunctive order. Instead, the Justice Department must petition the court to issue an injunctive order. However, the Federal Trade Commission may directly issue civil injunctive orders under Section 11 of the Clayton Act. ${ }^{46}$ Also, under the
43. Id. art. 17.
44. Id. art. 20.
45. Id. art. 29.
46. 15 U.S.C. $\ 21$. 
Sherman Act, the Justice Department may initiate a criminal complaint for violations, or threatened violations, in court ${ }^{47}$ However, under the New Law, the enforcing agencies may not directly make criminal complaints in court. Rather, it is the function of another government agency, the People's Prosecution Offices, to initiate criminal prosecution. Finally, under both the Clayton Act and the FTC Act, the Justice Department Shares authority with the Federal Trade Commission to enforce Sections 2, 3, 7 and 8 of the Clayton Act. In contrast, under the New Law, the enforcing agencies have exclusive power to enforce the New Law.

Under section 5 of the FTC Act, the Federal Trade Commission has the power not only to crack down on unfair methods of competition which are prohibited under the Sherman and Clayton Acts, but also to reach those unfair or deceptive acts or practices, such as fraudulent advertising and misleading product promotion techniques, and other acts or practices which the Federal Trade Commission may deem "unfair." However, under the New Law, the enforcing agencies' power over unfair acts is explicit and definite, and it may not be extended to any acts beyond those enumerated in the New Law.

The power vested in the Federal Trade Commission under the Sherman Act, the Clayton Act and the FTC Act is supplemental to the power vested in the Justice Department in various antitrust statutes. The Justice Department enforces the laws through the courts, regardless of whether the proceeding is civil or criminal in nature. Under the FTC Act, the proceeding pursued by the Federal Trade Commission is always administrative and purely civil in nature. Furthermore, the Federal Trade Commission may issue civil injunctive orders against any party it deems to have violated the FTC Act, although such injunctive orders are subject to judicial review. Finally, both the Sherman and Clayton Acts may be enforced by private parties, whereas the FTC Act can only be enforced by the Federal Trade Commission. Like the enforcing agencies under the New Law, the Federal Trade Commission has extensive investigative powers under the FTC Act, such as: (1) Issuing subpoenas to order individuals to attend hearings, giving testimony, and producing documentary evidence; ${ }^{48}$ (2) directing individuals or entities to file reports or answer specific questions; ${ }^{49}$ and

47. See generally Sherman Act 1-3; Carla Hills, Antitrust Adviser (1985).

48. 15 U.S.C. $\$ 49$.

49. Id. $\ 46$. 
(3) obtaining documents related to investigation for examination and copying. ${ }^{50}$

\section{Conclusion}

The above discussion leads to the conclusion that the New Law symbolizes the beginning of fair competition protection legislation in China. As China's first anti-unfair competition/antitrust law statute, the New Law does not prohibit most traditional antitrust law violations, which constitute the core part of the U.S. antitrust laws. The New Law does list certain violations which are not seen in, or normally considered part of, U.S. antitrust laws. In addition, the New Law provides remedies and penalties for violations which are different from those provided under U.S. antitrust laws. Such differences show both in the degree of imposing penalties and in the variety of remedial or punitive measures. Finally, differences exist between the New Law and the U.S. antitrust laws regarding law enforcing agencies and procedures.

The New Law reflects the transitional changes taking place in China. On one hand, the New Law seeks to encourage and protect fair competition, and to prohibit government agencies and certain enterprises with administrative functions from abusing their powers and privileges vested by the law. On the other hand, the New Law fails to define what constitutes "abuse." The transitional setting in China will make it extremely difficult to enforce certain provisions in the New Law, such as Article 6 and Article 7, relating to acts by public utilities and exclusive dealers, and acts related to administrative functions, respectively.

Finally, since the New Law only applies to those acts expressly enumerated, the enforcing agencies may not reach beyond those acts. Such rigid legislative tactics make the New Law very inflexible in China's fast-changing economy. There must be revision of the New Law or enactment of other new laws for the enforcing agencies to be able to reach any type of new unfair competitive conduct which might occur. To solve this problem, it seems that a provision filling the legislative gap like Section 5 of the FTC Act needs to be added to the New Law or to be created through separate legislation. 